\section{E-LOGOS}

ELECTRONIC JOURNAL FOR PHILOSOPHY ISSN 1211-0442

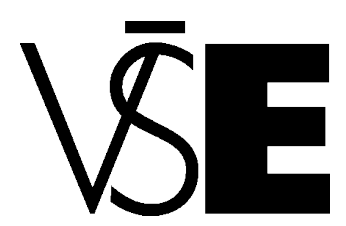

University of Economics

Prague

\title{
Sociálna forma pohybu hmoty (a jej hlavné, štruktúrne prvky)
}

\author{
Robert Burgan
}

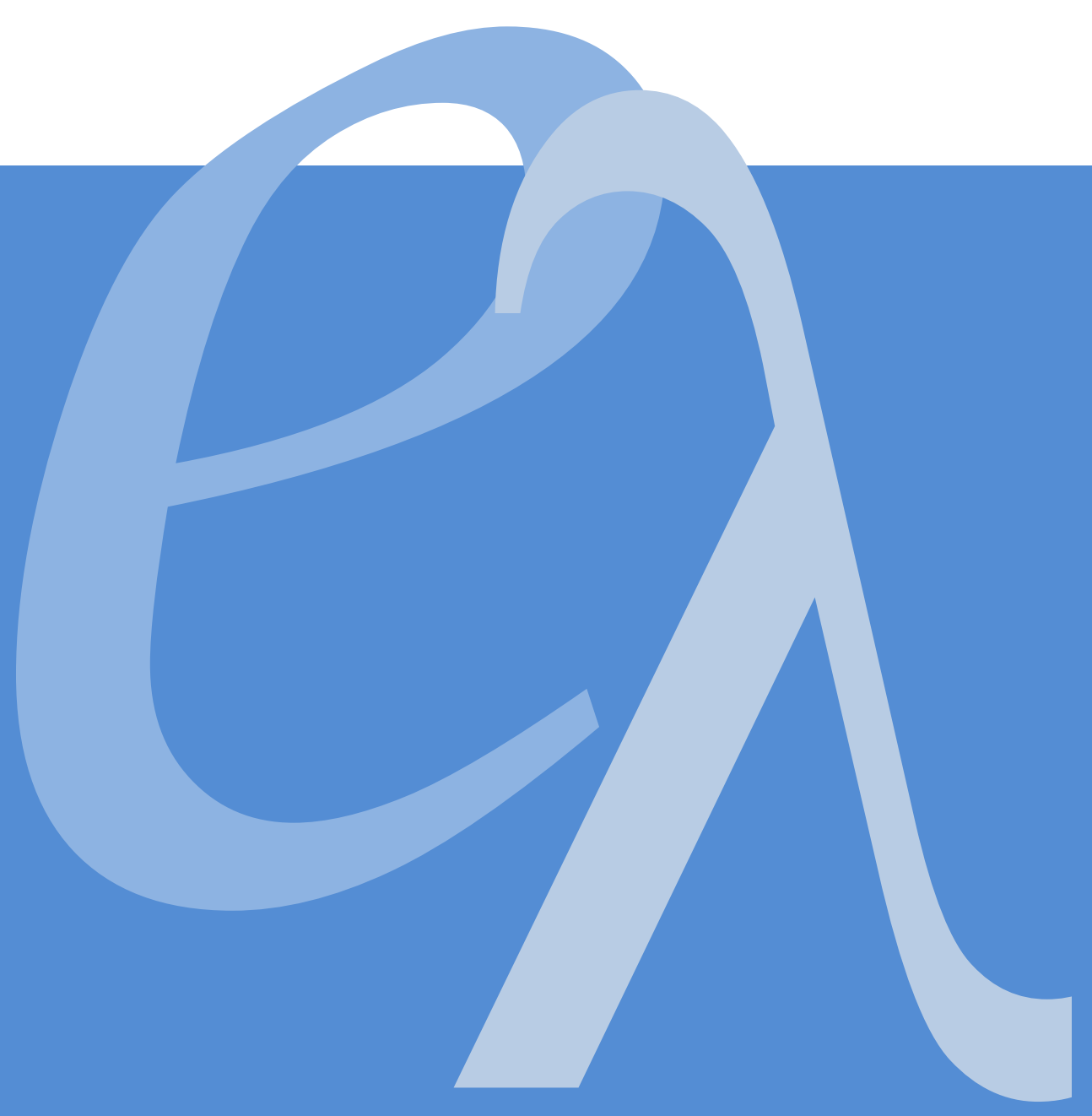




\begin{abstract}
Simultaneously with the definition of social form of moving are in the following parts of this paper discussed the borderline between biological and social phenomenon, the substance and key structural elements of social form of moving and in the end the possible extinction of social form of moving or its substitution by entirely new supersocial form of moving with its own structural elements and laws of motion.
\end{abstract}

\title{
Keywords
}

form of moving; biological form of moving; social form of moving; postsocial form of moving 


\section{Úvod}

Každá vedecká disciplína má operatívne vymedzené hranice svojho výskumu, v rámci ktorých sa jej bádatelia môžu relatívne vol'ne pohybovat', riešiac staré i nové problémy s pomocou osvedčených i novozavedených výskumných metód, techník alebo procedúr. Len zriedkavo však dochádza $k$ tomu, že niekto sa odváži spochybnit' platnost' týchto hraníc, resp. poukázat' na ich „neostrost"“, vzájomné prekrývanie sa alebo prelínanie výskumných oblastí či dokonca poukázat' na možnú časovú a existenciálnu ohraničenost' niečoho pre nás tak samozrejmého, ako je l'udská spoločnost', jej rôzne vel'ké a rôzne významné jednotky a podsystémy. V tomto vyslovene diskusnom príspevku sa pokúsime dokázat', že všetky úvahy o možnom prekonaní sociálneho nadsociálnym a vzniku úplne novej formy pohybu hmoty sú nielen epistemicky zaujímavé a podnetné, ale $\mathrm{v}$ danom historickom a technickom kontexte aj úplne korektné.

\section{Forma pohybu hmoty}

Ako bolo až donedávna všeobecne známe, kategóriu forma pohybu hmoty zaviedol F. Engels vo svojej Dialektike prírody (1963), kde často a opakovane hovoril o mechanickej, fyzikálnej, chemickej a biologickej forme pohybu hmoty, dôkladne skúmal prechod od živých systémov k l'udskej bytosti a spoločnosti, ale s pojmom „sociálna forma pohybu hmoty“ ako takým vôbec nepracoval, súc si vedomý existencie takých t'ažko uchopitel'ných, slabo preskúmaných a preto aj mimoriadne sporných fenoménov, ako sú psychično, vedomie a l'udská mysel'. Na druhej strane bol to práve F. Engels, kto zdôraznil, že „rozličné formy a druhy látky možno poznat” iba prostredníctvom pohybu“, pretože „iba v ňom sa prejavujú vlastnosti telies“ (ibid, s. 198), a na tomto základe navrhol takú klasifikáciu vied alebo vedných disciplín, ktorá vychádza zinherentného poriadku jednotlivých, po sebe nasledujúcich foriem pohybu hmoty.

Marxistickí filozofi preto v uplynulom storočí bežne hovorili o mechanickej, fyzikálnej, chemickej, biologickej a sociálnej forme pohybu hmoty, či mikroskopickej, makroskopickej a kozmickej, alebo subatomárnej, atomárnej, molekulovej, bunkovej a sociálnej forme pohybu hmoty (Dubnička, J., 1989, s. 274), ale vo väčšine prípadov sa hlbšie nezamýšlali nad tým, aké sú kritériá, na základe ktorých vyčleňujeme jednotlivé formy pohybu hmoty, či okrem piatich vyššie uvedených základných foriem pohybu nemôžeme vyčlenit' aj d'alšie, a dokonca ani nad tým, nakol'ko užitočná je táto kategória v konkrétnom špeciálnovednom (a teda aj v sociologickom) výskume. Jednou z mála výnimiek je tu I. F. Zubkov, ktorý vo svojej málo známej knihe (1981) nielenže vyčlenil popri piatich vyššie uvedených pohybových formách aj viacero d'alších (vrátane atómovej, mineralogickej, petrologickej, planetárnej či geologickej), ale uviedol aj kritériá, na základe ktorých takto vo svojej práci postupoval (ibid, s. 134-153). 
Podl'a Zubkova každá forma pohybu hmoty predstavuje určitý stupeň vo vývine prírody, „ktorý je podmienený predchádzajúcim a sám podmieňuje nasledujúci“ (ibid, s. 31), pričom hranice každého objektu vedeckého výskumu (a teda aj každej formy pohybu hmoty) sú určované len jeho pohybom, jeho spôsobom existencie, čiže celým súhrnom „procesov, ktoré podmieňujú vznik, existenciu a vývin práve tohto objektu“ (ibid, s. 32). Základom existencie každého takéhoto organického objektu (alebo systému) je preto energeticko-látková výmena, resp. kolobeh medzi jeho historicky vzniknutými protikladnými čast́ami, ktorého špecifickost' (a pravidelnost') je vyjadrovaná novými zákonmi, novými formami univerzálneho pohybu, na základe čoho potom Zubkov definuje formu pohybu hmoty ako „spôsob existencie celostných systémov - stupňov vývinu prírody, ktorého podstata spočíva v procesoch výmeny (kolobehu) medzi protikladnými častámi každého jednotlivého systému“ (ibid, s. 101; podč. I. Z.).

Po rozlíšení jednotlivých štruktúrnych úrovní a ich prvkov v neživej i živej prírode potom už môžeme sledovat', ako sa až do určitého momentu jednotlivé štruktúrne úrovne (a formy pohybu) hmoty (od hmlovín po planéty) postupne zmenšujú, zatial' čo ich štruktúrne prvky (od elementárnych častíc po minerály a agregáty) naopak postupne zväčšujú, resp., ako vo vzt’ahu k celému vývinovému radu neživej a živej prírody tvrdí A. D. Ursul, postupne vzrastá celkové množstvo informácie tak v jednotlivých vývinových stupňoch, ako aj vich prvkoch (ibid, s. 151-152). V rámci sociálnej formy pohybu hmoty sa nakoniec rozdiel medzi celkom a čast'ou takmer úplne stiera a relativizuje, pretože, ako uvádzajú I. Prigogine a I. Stengersová (2001, s. 185), „v spoločenstvách, ktorých jednotlivci nie sú navzájom zamenitel'ní a každý má svoju vlastnú pamät', charakter a skúsenost' a kde každý z nich má svoje postavenie, sa význam evolučnej rovnice a všeobecnejšie aj darvinovského myslenia stáva relatívnym“.

\section{Sociálna forma pohybu hmoty}

V prvom priblížení by sme hádam mohli konštatovat', že sociálna forma pohybu hmoty je v podstate totožná s l'udskou spoločnost'ou. Samotná (l'udská) spoločnost' je však zhl'adiska mnohých sociológov natol'ko rozsiahlym, rozmanitým a dynamickým fenoménom, že údajne ani nemá zmysel, ako tvrdia, pokúšat' sa o jeho jednoznačné vymedzenie (alebo definovanie). Podl'a J. Kellera (1992, s. 10) obyčajní l'udia a aj samotní sociológovia pod spoločnost'ou väčšinou rozumejú ten štát, tú konkrétnu národnú (alebo mnohonárodnostnú) skupinu l'udí, v ktorej práve žijú. Niektorí sociológovia zas pod spoločnost'ou rozumejú najmä modernú spoločnost' „so všetkými jej znakmi, vrátane vysokého stupňa industrializácie, urbanizácie, rozvinutej masovej komunikácie a pod.“ (ibid, s. 11), kým d’alší sa domnievajú, že spoločnost' ako taká vôbec neexistuje, pretože empiricky (alebo konkrétne) existujú „len jednotliví l'udia so svojimi záujmami a svojím konkrétnym správaním“ (ibid), s čím sa stotožňuje aj J. Keller. 
V rámci Parsonsovej sociologickej koncepcie sa už spoločnost' chápe ako siet' „všetkými príslušníkmi sociálne uznávaných (shared) významov, hodnôt a presvedčení“ (in Alijevová, D., 1999, s. 22), t. j. ako niečo čisto ideálne a intersubjektívne, pričom v rámci tzv. systémovej ekofilozofie J. Šmajsa a jeho stúpencov sa už sociálne úplne rozpúšta v kultúrnom, pretože do opozície voči tzv. onticky prirodzenej prírodnej evolúcii sa nestavia ani l'udská spoločnost', ani l'udská civilizácia, ale kultúrna evolúcia (resp. kultúra ako taká) ako „l'udskou aktivitou vytváraný systém s vlastnou vnútornou informáciou, ktorou je kultúra duchovná" (Šmajs, J., 2008, s. 103; podč. J. Š. $)^{1}$. O niečo precíznejší je v tomto prípade J. Keller, ktorý vo svojej knihe označuje ako kultúrne „všetko, čím sa človek odlišuje od zvierat'a“, tvoriace tak „súbor činností a výtvorov tejto činnosti, ktoré l'ud'om umožňujú prežit” v prírodnom prostredí“ (ibid, s. 159), otvárajúc tak d’alším bádatel'om cestu k ovel'a presnejšiemu vymedzeniu sociálneho.

Ako totiž d’alej uvádza J. Keller, kultúrnu premenu prírodného prostredia realizujú l'udia len vo vzájomnej koordinácii alebo spolupráci, ktorá je zaist'ovaná „zvládnutím komunikácie prostredníctvom symbolov“ (ibid). Sociálne interakcie sa tak prednostne uskutočňujú $\mathrm{v}$ rámci široko ponímaného kultúrneho styku a symbolickej komunikácie, s čím by však sotva súhlasil P. Sýkora, ktorý vo svojej dost' kŕčovitej snahe etablovat' sociobiologický výskumný program aj v rámci slovenskej sociológie definoval sociálnost' ako mieru "vzájomných interakciú medzi jedincami toho istého druhu“, ktorej stupeň „je určený tým, do akej miery je limitovaná autonómnost' a egocentrickost' správania“ (Sýkora, P., 1999, s. 378; podč. P. S.), čím sa jasne dištancoval od štandardného „vertikálneho členenia skutočnosti“, pri ktorom sa sociálne fenomény umiestňujú na vrchol "ontologickej hierarchie“, aby následne uzavrel, že najviac socializované sú tie spoločenstvá, ktorých integrácia vyúst'uje až do úplnej straty individuality ich členov a ich nutnej špecializácie v rámci spoločenstva - t. j. úle, mraveniská a termitištia.

Pri socializácii l'udských jedincov však naopak sledujeme, že namiesto úplnej straty individuality a jednostrannej špecializácie títo jedinci popri tom, že sa musia prispôsobit' všeobecne (alebo skupinovo) uznávaným normám a hodnotám, zároveň získavajú možnost' individuálne sa realizovat' a rozvíjat'. Aj preto ${ }^{2}$ si myslíme, že pri

\footnotetext{
${ }^{1}$ Podl'a Šmajsa by pritom širšia verejnost' mala vediet', že ,,aj kultúrne bytie je evolučne konštituované a že ako fyzické bytie môže vznikat' len zo staršieho bytia prirodzeného“ (ibid). Na rozdiel od J. Kellera však J. Šmajs o pár riadkov d'alej podl'a nás celkom správne zdôrazňuje, že aj ked' je jedinec hlavným nositel'om vlastností spoločenského systému, o fungovaní a vývoji tohto systému skôr rozhodujú nadindividuálne štruktúry a vzt'ahy. ${ }^{2}$ Informovaní čitatelia určite vedia, že ide o problém, ktorého dôkladné posúdenie by si vyžiadalo ovel’a viac priestoru, ako tu máme k dispozícii; aj tak si ale dovolíme poznamenat, že, po prvé, jeho podstatu ovel'a hlbšie ako P. Sýkora pochopil F. Engels, ked' pri tzv. hmyzích štátoch konštatoval, že ide len o nábeh $k$ sociálnemu, ktorý však nemá „Všeobecný účinok“ (ibid, s. 250), a po druhé, že organizačné a integračné procesy v rámci živého (a sociálneho) sa skôr rozvíjajú v línii, ktorú nedávno naznačil a rozpracoval J. Stewart (2000, s. 31-59), ked' po opísaní tzv. príbuzenského výberu (angl. kin selection) a recipročného altruizmu dôsledne rozlíšil medzi tzv. interným a externým manažmentom, pri ktorom je v prvom prípade kooperácia alebo súčinnost' daných jedincov zabezpečovaná s pomocou genetických alebo morálnych predispozícií, zatial' čo v druhom ju zvonka
} 
vymedzovaní sociálneho je vhodnejšie postupovat' spôsobom, ktorý si zvolil A. Hirner, ked' na základe dôkladného štúdia špecifických a rôzne vel'kých sociálnych fenoménov (l'udskej osobnosti, továrne, dediny, regiónu a vel'kej spoločenskej organizácie) vypracoval svoj viacrozmerný model sociálneho systému, ktorý úzko korešponduje „so systematicky usporiadaným súborom štruktúr sociálnej reality“ (in Schenk, J., 2000, s. 530), pričom zahrňuje 12 základných charakteristík a zložiek. ${ }^{3}$

Za zmienku tiež stojí definícia vesmírnej civilizácie ako takej, vypracovaná už dávnejšie T. A. Berzinovou (in Rubcov, V. V. - Ursul, A. D., 1984, s. 82) podl'a ktorej civilizácia v rámci problematiky SETI (Search for extraterrestrial intelligence) je „jednotlivým prejavom sociálnej formy pohybu, základnými vlastnostami ktorého sú materiálno-výrobná činnost' ako hlavná forma vzájomného pôsobenia sokolitým prostredím a existencia ideálnej formy odrazu skutočnosti (vedomia, rozumu)“ (podč. R. B.), obsahujúca obidve najhlavnejšie zložky danej formy pohybu. Ani táto definícia, ani Hirnerov model sociálneho systému nám ale nedovol'ujú vidiet' sociálne v jeho postupnom vývine, $\mathrm{v}$ jeho historickej ohraničenosti a efemérnosti, kedy sociálne (presnejšie, l'udská spoločnost' v určitom okamžiku svojich dejín) zahrňuje v sebe tak prekonané (a integrované) biologické, ako aj nadsociálne, t. j. tú a takú kvalitu, ktorej plné realizovanie (sa) už nie je v možnostiach postupne sa završujúcej sociálnej pohybovej formy. K jeho možným podobám sa ale budeme môct' vyjadrit' až po dôkladnom objasnení genézy sociálnej formy pohybu hmoty a následnom určení jej podstatotvorných, štruktúrnych prvkov.

\section{Zrodenie sociálneho (a kultúrneho) v lone biologického a prírodného}

Medzi antropológmi a paleoantropológmi dnes v podstate prevažuje názor, že najvhodnejšie je definovat' súčasného (alebo anatomicky moderného) človeka druhu Homo sapiens sapiens ako subjekt s bio-sociokultúrnou podstatou (Plichtová, J. Popper, M., 2005, s. 9) ${ }^{4}$. Spory sa ale stále zatial' vedú o to, kedy k jej vzniku alebo dotvoreniu definitívne a jednoznačne došlo, t. j. o to, kedy môžeme surčitostón hovorit' o vzniku novej l'udskej bytosti a spoločnosti, v rámci ktorej bol biologický typ adaptácie (na meniace sa prírodné prostredie) definitívne nahradený alebo vystriedaný kultúrnym typom adaptácie. Podl'a McBreartyovej a Brooksovej (2000) sa napríklad moderné správanie, vyznačujúce sa abstraktným myslením, dlhodobým plánovaním, technologickými inováciami a schopnost́ou produkovat' nástoroje a symboly objavilo u tzv. Homo helmei už pred 250 až 400 tisíc rokmi, čo vraj stavia na

zavádza a kontroluje zretel'ne vyčlenený externý „manažér“, ktorý sa snaží zneškodnit' a pacifikovat' všetkých klamárov a príživníkov v ním riadenom systéme, aby mohol mat’ z jeho fungovania čo najväčší prospech.

${ }^{3}$ Globálnu štruktúrovanost', relatívnu uzavretost', samoreguláciu, dynamickost', členenie na riadiace centrum a periférne zložky, hierarchickost', status, silu vnútorných väzieb atd’. (ibid, s. 530-531).

${ }^{4} \mathrm{~S}$ čím sa plne nestotožňujeme, pretože podl'a nás by bolo skôr vhodnejšie a výstižnejšie hovorit' o jeho biopsycho-sociokultúrnej podstate (a jednote) a zahrnút tak do jeho operatívnej definície aj psychické ako také. 
hlavu všetky tradičné tvrdenia o náhlej kultúrnej revolúcii na začiatku mladšieho paleolitu (ibid, s. 30) ${ }^{5}$.

J. Plichtová (odvolávajúc sa najmä na práce F. d’Errica a spol.) v tom istom duchu tvrdí, že už neandertálci „sa dopracovali k modernému správaniu vlastnou cestou“, pričom ani ich špecifická anatómia im vraj nebránila "produkovat' artikulované zvuky" na tej istej úrovni komplexnosti, ako to dokázal a dokáže Homo sapiens sapiens. Viacerí archeológovia (sic!) sa preto podl'a nej „prikláňajú k hypotéze, že neandertálci už mali jazyk“ (ibid, s. 31-32). Ešte d'alej ide Ch. Wills, ktorý sa domnieva, že zhromaždené genetické a paleontologické dôkazy jednoznačne potvrdzujú, že hominidi s vysokou úrovňou inteligencie, schopnost'ou vyrábat' nástroje a komunikačnými spôsobilost́ami „sa nezávisle vyvinuli viac ako jedenkrát" (Wills, Ch., 2008, s. 54), a to nielen v Afrike (naši vlastní predkovia, kromaňonci), ale aj v Európe (neandertálci) a v juhovýchodnej Ázii (známi trpaslíči "I'udkovia“ z indonézskeho ostrova Flores); takisto predpokladajúc, že neandertálcom nič nebránilo komunikovat' na našej úrovni.

P. Lieberman (aj ked' sa tiež zastáva hypotézy o postupnom vzniku jazyka) však uvádza, že na základe dôkladnej analýzy nadhrdlového zvukového traktu raných australopitekov došli anatómovia k záveru, že títo nemohli vyslovovat' samohlásky "i“ , „ $\mathrm{u}^{\prime \prime} \mathrm{a}$ „a“; dokonca aj lebky neandertálcov vraj rástli inak ako lebky anatomicky moderných l'udí (AML), v dôsledku čoho ich artikulačné orgány nikdy nenadobudli taký tvar, aby mohli vyslovovat' samohlásku „i“", ktorá svojou zretel'nost'ou a prenikavost́ou vel'mi ul'ahčuje vnímanie a dešifrovanie l'udskej reči (Lieberman, P., 2002, s. 56). Podl'a D. Bickertona, ktorý pôvodne tiež patril medzi zástancov hypotézy o postupnom vzniku jazyka, zas musela syntax (a spolu s ňou aj rozvinutý alebo plnohodnotný jazyk) vzniknút’ náhle a rýchlo, po prekročení kritického neurologického prahu u prvých AML, čo nepriamo vyplýva tak z vel'mi pomalého rozvoja ranopaleolitickej a strednopaleolitickej „industrie“, ako aj zo špecifických vlastností syntaxe samotnej, ktorá v žiadnom prípade nemohla vzniknút’ po častiach a postupne (Bickerton, D., 2003, s. 14-15).

To isté si v podstate myslí aj B. F. Poršnev, ktorý dokonca nepovažuje ranopaleolitické a strednopaleolitické kamenné nástroje za l'udské, ale len za zvláštne „prírodné novotvary“, prostriedky na spracovanie zvyškov vel’kých zvierat, ktoré by teda ani nemali byt' chápané a klasifikované ako pracovné nástroje v pravom slova zmysle (Poršnev, B. F., 1979, s. 111). Podl'a neho až rozvinutá kamenná, kostená i drevená industria prvých AML, ktorí sa objavili v Európe pred 40 až 45 tisíc rokmi svedčí o tom, že práve v tomto období sa utvorila l'udská reč a mozog sa začal rýchlo vyvíjat' do svojej súčasnej podoby, čo poskytlo AML také vel'ké evolučné výhody, že

\footnotetext{
5 Archeológovia pritom argumentujú spojitost'ou medzi „zložitejšou technológiou, symbolizmom a jazykom“, ktorá podl'a všetkého „tkvie v tom, že tieto spôsobilosti sa nedajú odovzdávat’ z jednej generácie na druhú bez podpory lingvistickej komunikácie“ (Plichtová, J., in Plichtová, J. - Popper, M., c. d., s. 27; podč. R. B.).
} 
v krátkom čase populačne predstihli všetkých svojich menej vyvinutých konkurentov a osídlili skoro celú Zem; čomu nakoniec neprotirečí ani Plichtovej tvrdenie, že istý čas prebiehala biologická evolúcia spolu s kultúrnou, pričom kultúrna evolúcia definitíone vystriedala biologickú až vtedy, ked' sa náš mozog vyvinul do súčasnej podoby (ibid, s. 37).

Na druhej strane je to práve Plichtovej dôkladná analýza vzájomného vzt'ahu kultúrneho a sociálneho v l'udskej evolúcii, ktorá nám umožňuje jasne odlíšit' biologické od sociálneho a posunút' sa zase o krôčik d'alej v našom výklade. Signifikantná je v danej súvislosti najmä táto Plichtovej poznámka: "Jedinou špecificky l'udskou formou šírenia kultúrnych variantov je teda učenie prostredníctvom jazyka“ (ibid, s. 47), ktorá by podl'a nás a pravdepodobne aj podl'a B. F. Poršneva i D. Bickertona mala zniet' trochu inak, presnejšie - najdôležitejšou formou šírenia kultúrnych variantov je učenie prostredníctvom jazyka, pretože, ako tvrdí B. F. Poršnev na základe vyššie uvedenej argumentácie, vedomie a psychický život môžu mat' len moderní sapienti, ktorí ako jediní hovoria a ciel'avedome pracujú (ibid, s. 122-123 a i.) ${ }^{6}$. Aj ked' teda uznávame dôležitost' tzv. kultúrneho, sociálneho alebo imitačného učenia počas celej evolúcie od prvých vzpriamene chodiacich bytostí až k prvým AML, predsa len si myslíme, že aj v tomto prípade máme do činenia len so špecifickým prejavom biologickej evolúcie ${ }^{7}$.

Ani Plichtovej vymedzenie sociálneho (alebo sociálnosti) ako zvláštnej a postupne sa rozvíjajúcej (či zdokonalujúcej) schopnosti hominidov sústredene vnímat', vyhodnocovat' a následne aj predvídat' správanie ostatných, empaticky prežívat' emocionálne stavy svojich "rodných" a zároveň s nimi aj čoraz účinnejšie spolupracovat', podl'a nás plne nevystihuje jeho špecifickost' (a podstatu), pretože sa pri ňom neberie do úvahy špecifický ráz sociálnych interakcií, realizujúcich sa medzi bytost'ami disponujúcimi plne rozvinutou rečou (a takisto aj myslením), ani ich historická podmienenost' dosiahnutým stupňom vo vývine výrobných síl spoločnosti, ktorý (v závislosti od svojej produktivity a efektivity) priamo ovplyvňuje celkový počet kooperujúcich indivíduí v spoločnosti, jej štruktúrovanost' do rôzne vel'kých skupín i vzájomné vzt’ahy medzi týmito indivíduami a skupinami. Aj preto sme presvedčení, že ak chceme presne vymedzit' podstatu sociálnej formy pohybu hmoty a jej hlavné - štruktúrne - prvky, musíme najprv jednoznačne odlišit’ (a "odčlenit" ${ }^{\prime \prime}$ spoločnost' od kultúry a civilizácie.

\footnotetext{
${ }^{6}$ Ako navyše d'alej upozorňuje B. F. Poršnev, rozhodujúci pritom nebol celkový rast mozgu, ktorý sa u prvých AML už nezväčšoval, ale po vzniku syntaktickej reči rástol dopredu a do výšky, a to práve v tých oblastiach, ktoré by mali riadit' rečovú činnost', ako aj naše ciel'avedomé a časovo viazané (čiže zámerné a plánovité) správanie, aby sa napokon vyvinul do svojej súčasnej podoby pred 15 až 25 tisíc rokmi (ibid, s., 356-359, 402).

${ }_{7}$ Pokial' ide o samotný prechod alebo vývin od prvých vzpriamene chodiacich bytostí k prvým AML, nazdávame sa, že najvýstižnejšie a najpresnejšie ho opisuje a analyzuje práve B. F. Poršnev na základe neurologických a behaviorálnych mechanizmov (alebo procesov), ako sú inštinktívne napodobňovanie, neadekvátne reflexy, interdikcia a generalizovaná interdikcia (bližšie pozri c. d., najmä s. 269-339, 400, 410, 451).
} 


\section{Podstata sociálnej formy pohybu hmoty a jej hlavné (štruktúrne) prvky}

Tentoraz začneme od konca. Hlavnými, štruktúrnymi prvkami sociálnej formy pohybu hmoty sú podl'a nás jednotliví l’udia, chápaní nie(len) ako fyzikálne a biologické objekty (súbory špecificky integrovaných atómov, molekúl a buniek), ale aj a najmä ako sociokultúrne bytosti, nositelia relatívneho samopohybu, samoregulácie a samoorganizácie jednotlivých sociálnych systémov (Schenk, J., 1990, s. 167), ktorí na jednej strane iniciujú sociálne interakcie a zmeny a na strane druhej sú týmito zmenami zasahovaní a ovplyvňovaní, vystupujúc tak jednak ako plne autonómne bytosti a zároveň ako zložky nimi vytváraných sociálnych štruktúr (či sietí) a prekonávajúc v takejto dialektickej súvzt́ažnosti napokon aj „večný“ antagonizmus medzi singulárnym a holistickým v modernej sociológii, ktorá vo väčšine prípadov bud' redukuje sociálne na individuálne (postoje, hodnotenia či mienky) a „spoločnost' na súčet jednotlivcov, ktorí ju tvoria“, alebo uznáva len „nadindividuálne a od jednotlivca (jeho aktivity, slobody) odtrhnuté (holistické, prísne deterministické - R. B.) celky, sociálne útvary“ (ibid, s. 18-19).

Takto vymedzená sociálna forma pohybu hmoty zahrnuje v sebe tak l'udskú spoločnost' (ako súbor jedincov, nimi tvorených skupín a vzájomných vztáahov medzi nimi), ako aj všetky činnosti a predmety, s pomocou ktorých títo jedinci a tieto historicky sa formujúce skupiny interagujú s okolitou prírodou, t. j kultúru v širokom slova zmysle, pričom jednoznačne vzniká v tom momente, ked' prví AML začínajú hovorit' a produkovat' industriu mladšieho paleolitu, ktorá im umožňuje definitívne sa vyčlenit' zo živej prírody $^{8}$, a zaniká, resp. môže zaniknút' až potom, ako sa podstatne zmenia tak štruktúrne proky tejto formy pohybu hmoty, ako aj spôsob, akým interagujú sokolitou prírodou a medzi sebou. Je takisto zrejmé, že súčast'u sociálnej formy pohybu hmoty sú aj jednotlivé historicky vznikajúce civilizácie (ako formy jej prejavu i jedinečné sociokultúrne celky), ktoré sa môžu objavit' len v takých komunitách, ktoré dokážu interagovat' s okolitou prírodou natol'ko efektívne, že dokážu vytvorit' nadprodukt a ten určitý čas investovat' do tvorby organizačných a hierarchických sociálnych (a triednych) štruktúr.

Otáznym zostáva len vzájomný vzt'ah medzi civilizáciou a kultúrou, presnejšie, široké vymedzenie kultúry ako „súboru činností a výtvorov tejto činnosti, ktoré l'ud'om umožňujú prežit’ v prírodnom prostredí“, pretože v antropológii a kulturológii existujú aj d’alšie definície (alebo koncepcie) kultúry, ako napríklad axiologická, podl'a ktorej je kultúra zdokonalením, zušl'achtením a zjemnením

\footnotetext{
${ }^{8}$ Pre úplnost' ale uved'me, že podl'a B. F. Poršneva sociálna forma pohybu hmoty začala pravdepodobne existovat' až vtedy, ked' sa mozog prvých AML definitívne vyvinul (pred 15 až 25 tisíc rokmi) do svojej súčasnej podoby, ako to priamo vyplýva aj z jeho poznámky, že „iba od tých čias, ked’ sa menia nástroje, no druh sa stabilizuje, možno hovorit' o výrobe vo vlastnom zmysle - o spoločenskej výrobe“ (ibid, s. 375; podč. R. B).
} 
celkových duševných a telesných síl osoby a l'udstva (Adelung, J. Ch., in Soukup, V., 2004, s. 278), globálno antropologická, podl'a ktorej je kultúra autonómna oblast', resp. komplexný celok, skladajúci sa zo všetkých produktov l'udskej činnosti, vrátane poznania, viery, umenia, morálky či zvykov (Tylor, E. B., ibid, s. 284), alebo redukcionistická a všeobecná, podl'a ktorej je kultúra výsledkom alebo prejavom špecifickej schopnosti l'udskej mysle byt' intencionálnou, aktívnou a kreatívnou (Bauman, Z., in Plichtová, J. - Popper, M., c. d., s. 115), ktoré pri všetkej svojej rozdielnosti môžu byt' zahrnuté do vyššie uvedenej Kellerovej definície kultúry ako rozrastajúceho sa civilizačného „obalu“ l'udskej spoločnosti.

Prenesene tak môže byt' aj samotná sociálna forma pohybu hmoty definovaná ako určitá bio-psycho-sociokultúrna jednota, čo by nám ale, ako upozorňuje opät’ B. F. Poršnev, nemalo prekážat' v jasnom uvedomení si toho, že najvyššou formou pohybu hmoty nie sú spoločenské vzt'ahy, ale myslenie, l'udské vedomie (a reč), vyvolané k životu v rámci počiatočnej pracovnej činnosti (ibid, s. 383), ktoré, súc uložené v telesných schránkach jednotlivých l'udí - nositel'ov sociálnej formy pohybu, nám v dlhom slede generácii na jednej strane umožnili preniknút' čoraz hlbšie do štruktúry okolitej neživej, živej (a nakoniec aj sociálnej) prírody a s pomocou takto získaných poznatkov postupne vytvorit' niekol'ko čoraz výkonnejších produkčných či hospodárskych systémov (bežne označovaných ako otrokárska, feudálna alebo kapitalistická spoločnost') a na strane druhej $v$ takto zdokonalenom civilizačnom (alebo kultúrnom) „obale“ postupne racionalizovali všetky naše činnosti a pomohli jednotlivým l'ud'om z vel'kej časti sa vymanit' z historicky prechodnej majetkovej, mocenskej (a triednej) podriadenosti i závislosti. Bohužial', l'ud'mi vytvorený civilizačný "obal“ (všetky tie automobily, buchary, fény, mosty, spinky a iné „životne dôležité" stroje, prístroje a nástroje) sa natol'ko rozrástol, zdynamizoval a "skomplikoval“, že l'udia a ich sociálne inštitúcie ho už svojimi vlastnými konceptuálnymi a riadiacimi prostriedkami zvládnut' nedokážu. Práve preto čoraz väčšiu čast' myšlienkovej práce presúvajú do strojov (počítačov, automatických výrobných systémov atd'.) a práve preto sa z hlbín sociokultúrneho začína vynárat' niečo donedávna celkom nepredstavitel'né, t. j.

\section{Nadsociálna forma pohybu hmoty}

Ako je teda zrejmé, nadsociálna forma pohybu hmoty sa môže začat' konštituovat' až vtedy, ked' sa z väčšej časti vyčerpajú vývinové možnosti sociálnej formy pohybu hmoty, t. j. vtedy, ked' l'udia (združení do jednej vel'kej komunity alebo civilizácie) začnú strácat' kontrolu nad vývinom civilizačného "obalu“, ktorý sami vytvorili, pričom v tom istom momente svojich dejín sa zároveň pokúšajú zreteĺne vymedzit' aj rôzne varianty nadsociálnej formy pohybu, výrazne sa odlišujúce od všetkého, na čo sme doteraz boli zvyknutí alebo pripravení. Obidve tieto hypotézy sa teraz pokúsime dokázat', začínajúc najprv rôznymi príkladmi postupného vytláčania l'udí 
z globálneho vývojového procesu, resp. ich neschopnosti optimálne využívat' vol'né látkovo-energeticko-informačné zdroje a navzájom spolupracovat' pri dosahovaní tých skutočne dôležitých, t. j. nie krátkodobých a partikulárnych, ale globálnych evolučných cielov.

Po proé, ako upozorňuje J. A. Tainter (2009, s. 127-170, 274-282), sú l'udské spoločnosti a politické organizácie, podobne ako všetky živé systémy, udržiavané pri živote stálym tokom energie. Čím rozsiahlejšia a zložitejšia teda spoločnost' je, tým viac energie potrebuje a tým je aj náchylnejšia ku kolapsu, pokial' sa jej tejto energie nedostáva. Do zložitosti, t. j. do rôznych hierarchických riadiacich štruktúr, špecialistov atd'., teda treba investovat', pričom efektívnost' týchto investícií sa časom mení - spočiatku (vo fáze vzostupného vývoja) stúpa a neskôr (vo fáze úpadku) čoraz rýchlejšie klesá. Pôsobí tu totiž zákon klesajúcej hraničnej produktivity, vzt'ahujúci sa k zmenám v oblasti priemerných a hraničných produktov a nákladov ${ }^{9}$, ktorý si od každej spoločnosti, ktorá sa chce vyhnút' kolapsu, vyžaduje, aby v predstihu investovala do produktívnejších energetických zdrojov. Bohužial', ako d'alej podotýka Tainter, vo viacerých klúčových investičných sférach (zdravotníctvo, vzdelávanie, výskum atd'.) už zažívame pokles hraničných výnosov a pozvol'na sa tak približujeme $\mathrm{k}$ nestabilnej fáze tesne pred kolapsom. ${ }^{10}$

Po druhé, podl'a H. Magdoffa a P. Sweezyho (in Foster, J. B. - Magdoff, F., 2009, s. 100-103) je normálnym stavom vyspelých kapitalistických ekonomík USA, Japonska a vel'kých západoeurópskych krajín skôr stagnácia, ako sústavný a dlhodobý rozvoj, pretože vel'ká čast' kapitálových prebytkov generovaných najmä zásluhou neustále rastúcej produktivity systému nemôže byt' dostatočne výnosne investovaná, čo vyúst'uje do tzv. financializácie, pri ktorej je vol'ný kapitál namiesto do výroby investovaný do rôznych čisto finančných (a úverových) obchodov i fondov s dnes už všeobecne vel'mi dobre známymi katastrofálnymi následkami; zatial’ čo R. Hanson (2001, s. 2) poukazuje na to, že výrazný rast produktivity práce, spojený s rýchlym vzrastom výkonnosti počítačov a v nich pracujúcich programov, môže spočiatku viest' k rýchlemu rastu l'udských príjmov, ale po určitom čase začne dominovat'

\footnotetext{
${ }^{9}$ Podl’a Taintera (ibid, s. 129), odvolávajúceho sa pritom na práce J. Hadara (1966) a T. J. Hailstonesa (1976), „priemerný produkt nejakej ekonomickej aktivity je jednoducho výstup prepočítaný na jednotku vstupu“, kým „hraničný produkt určitého vstupu je nárast celkového výstupu, ktorý je dôsledkom onoho vstupu. Priemernými nákladmi podobne rozumieme náklady na jednotku výstupu, zatial' čo hraničným nákladom je vzostup (alebo pokles) celkových nákladov, ktorý je dôsledkom d’alšej jednotky výstupu (alebo naopak menšieho počtu jednotiek výstupu)“; čo možno znie trochu „kostrbato“, ale, ako d’alej uvidíme, zvyčajne má závažné dôsledky.

${ }^{10}$ Ten však môže byt' zničujúci najmä $\mathrm{v}$ industriálnych spoločnostiach, kde vel'a obyvatel’ov nemá príležitost' alebo nie sú schopní „produkovat’ primárne potravinové zdroje“, a tak by so sebou určite priniesol „ohromný rozvrat a nesmierne vel'ké straty na životoch, nehovoriac o výraznom znížení životnej úrovne tých, ktorí by ho prežili“ (ibid, s. 274), a to bez ohladu na to, nakol'ko by sa pri ňom zredukovali sociálne štruktúry alebo siete.
} 
substitúcia l'udských pracovných síl a mzdy začnú klesat' rovnako rýchlo ako ceny výpočtovej techniky ${ }^{11}$.

Po tretie, v rámci známej Wallersteinovej teórie svetových systémov (in Holubec, S., 2009, s. 28-36) tvorí svetová ekonomika jednotný (alebo globálny) systém, ktorý sa člení na krajiny centra, semiperiférie a periférie takým spôsobom, že krajiny semiperiférie a periférie sa len výnimočne presúvajú až do samého centra, ktoré si rôznymi ekonomickými, politickými a v krajnom prípade aj vojenskými prostriedkami udržiava svoju dominanciu, pričom zároveň nastavuje výrobné a obchodné podmienky tak, aby mohlo t'ažit' z nadproduktu chudobnejších (a slabších) periférnych a semiperiférnych krajín a d'alej zvyšovat' svoje zisky. Ako vzápätí zdôrazňuje S. Holubec (ibid, s. 72), v druhej polovici 20. storočia už dochádza vo svetovom systéme $\mathrm{k}$ znižovaniu tempa hospodárskeho rastu a k extrémnemu „prehlbovaniu rozdielov v bohatstve medzi jednotlivými krajinami“, ako aj vnútri nich; a podl'a nás aj k zvýšenému tlaku na vol'né surovinové a energetické zdroje v súvislosti s rozhodnutím čínskej a indickej politickej elity dostat' svoje krajiny do centra, čo pri predpokladanej životnosti týchto zdrojov (rátanej na desiatky rokov) musí skôr či neskôr viest' ku globálnym vojenským konfliktom ${ }^{12}$.

Po šturté, k záveru, že l'udské dejiny sa blížia k svojmu koncu (a nadsociálne onedlho prekoná a nahradí sociálne) môžeme nakoniec, ako objasňuje A. D. Panov (2004, 2005), dôjst' aj na základe tzv. synergetického modelu dejín, vypracovaného A. P. Nazaretjanom (2001), v ktorom je l'udská civilizácia chápaná ako jediný systém, ktorý sa zákonite vyvíja tak, že sústavne zvyšuje svoju technologickú úroveň aj populačný prírastok, pričom však opakovane prechádza rôznymi krízami zapríčinenými bud' devastáciou životného prostredia, zrýchleným technologickým rozvojom, kedy si spoločnost' nestačí včas vypracovat' účinné sociálno-kultúrne regulačné mechanizmy, alebo jedným aj druhým. Podl'a Panova (2004) sa však naša civilizácia ocitla na prahu nie jednej vel'kej krízy, ale celej série rýchlo po sebe nasledujúcich kríz, akejsi krízy kríz, vyznačujúcej sa exponenciálnym či dokonca až hyperbolickým rastom takých parametrov, ako sú populácia, výroba energie a spotreba neobnovitel'ných zdrojov, ako to vyplýva aj z tzv. škálovacieho zákona biologicko-kultúrnej evolúcie ${ }^{13}$, a skôr či neskôr bude nútená nielen prejst' na intenzívny typ rozvoja, ale aj využit' nadsociálnu formu pohybu hmoty

\footnotetext{
${ }^{11}$ V. Vinge (1993) dokonca upozorňuje, že už dnes je skutočne produktívna práca doménou čoraz menšej a výlučnejšej časti l'udskej populácie, pričom po prechode cez technologickú singularitu, akýsi zlomový bod, v ktorom sa končia, resp. do extrémne vysokých hodnôt (až nekonečna) divergujú všetky normálne historickoevolučné trendy, sa koncept technologickej nezamestnanosti stane definitívne skutočnost'ou.

${ }^{12} \mathrm{O}$ tom, vakej nebezpečnej situácii sa v skutočnosti nachádzame, svedčia aj správy z médií o arogantných plánoch čínskej vlády presmerovat’ toky všetkých tibetských riek, vrátane Brahmaputry, do Č́ny alebo snahe niektorých krajín z horného toku Nílu vybudovat’ na ňom priehrady a kontrolovat' tak jeho aktuálny prietok.

${ }^{13}$ Ako tvrdí Panov (2005), biologická evolúcia a l’udské dejiny predstavujú jednotný a kontinuálny proces, ktorý sa uskutočňuje vo viacerých po sebe nasledujúcich fázach, rozdelených fázovými prechodmi a skutočnými „revolúciami“ (alebo zásadnými kvalitatívnymi zmenami živého a sociálneho), pri ktorých sa uplatňuje vyššie
} 


\section{... a jej rôzne varianty (podoby či modely)}

Podl'a Panova (2004) ešte pred dosiahnutím daného singulárneho bodu (v ktorom by sa, čisto teoreticky, biologické a sociokultúrne „dejiny“ mali nekonečne zrýchlit” - čo je ale vzhl'adom na naše rýchlo sa zmenšujúce látkovo-energeticko-informačné zdroje, samozrejme, vylúčené), by mala l'udská civilizácia prejst' z extenzívneho vývojového režimu na intenzívny (kedy sa namiesto rozšírenej reprodukcie organických biologických a sociokultúrnych systémov začne uplatňovat' ich jednoduchá reprodukcia), čo ale povedie $k$ hlbokej kríze vedeckého poznávania a vôbec poznávania ako takého ${ }^{14}$, ktorú by l'udia podl'a neho mali prekonat' tak, že budú na jednej strane do obývatel'ných vesmírnych lokalít vysielat' súbor najdôležitejších poznatkov o svojich bio-sociokultúrnych dejinách ${ }^{15}$ a zároveň prijímat' podobné vysielanie z mnohých d'alších bio- a sociogénnych lokalít, využívajúc obrovské množstvo informácií z postupne sa rozširujúceho galaktického kultúrneho polá, v rámci ktorého budú jednotlivé postsingulárne civilizácie postupne spracovávat' prijaté informácie, d'alej ich prehlbovat' a "preposielat" celkové množstvo kultúrnych informácií v Galaxii a zároveň sa rozvinie množstvo štruktúrnych foriem pohybu hmoty, kvalitatíone preoyšujúcich rozum ${ }^{16}$.

Sám Panov ale uznáva (2004), že staršia a technicky zdatná galaktická civilizácia môže vjednom "balíku“ vysielat” aj informácie o miliónoch d'alších galaktických civilizácii a celých dejinách Galaxie, ktorých rozšifrovanie bude extrémne náročnou a vel'a času si vyžadujúcou operáciou, ktorú bude pritom musiet' realizovat' postsingulárna civilizácia nachádzajúca sa $\mathrm{v}$ intenzívnej a de facto stacionárnej fáze svojho rozvoja s mimimom vol'ných zdrojov, čo je podl'a nás nerealizovatel’ná úloha, pokial' táto civilizácia nevenuje vel'kú čast’ svojich zdrojov (v záujme svojho prežitia) na vývoj a prevádzkovanie tzv. umelej inteligencie s výpočtovou silou, ktorá

uvedený škálovací zákon, prejavujúci sa neustálym zrýchl’ovaním biologického a sociokultúrneho vývojového procesu, kedy každá nasledujúca vývojová fáza trvá o koeficient $\alpha=2,67 \pm 0,15$ kratšie ako predchádzajúca, čo pri jednoznačne určenom počiatku biologických a sociokultúrnych „dejín“ našej planéty vyúst’uje do záveru, že v jednom prípade dosiahnu tieto „dejiny“ singulárny alebo konečný bod okolo roku 2004 (Panov, A. D., 2005), zatial' čo v druhom (pri koeficiente $\alpha=2,42$ ) okolo roku 2027 (Panov, A. D., 2004; Vinge, V., 1993). V danom singulárnom bode sa pritom biologické a sociokultúrne „dejiny“ nemusia skončit'v doslovnom slova zmysle, skôr pôjde, ako tvrdí Panov a ako d’alej uvidíme, o ukončenie pôsobenia daného škálovacieho a akceleračného zákona a prechod na úplne iný, ovel’a „prirodzenejšl“" režim biologického a sociokultúrneho vývoja (Panov, A. D., 2004).

${ }^{14}$ Pretože na jeho rozvoj budú chýbat' vol’né látkovo-energeticko-informačné zdroje.

${ }^{15}$ Panov totiž aj na základe fyzikálnych teórií všetkého (angl. theories of everything - TOE) predpokladá, že fyzikálne poznávanie sa onedlho dostane do štádia, kedy už nebude poskytovat žiadne revolučné poznatky.

${ }^{16}$ Panov (2004) predovšetkým poukazuje na rozdiel medzi hypotetickou metacivilizáciou, pozostávajúcou z viacerých civilizácií, ktoré, podobne ako l’udské indivíduá v rámci našej civilizácie, môžu efektívne a rýchlo komunikovat', pretože charakteristický čas potrebný na informačnú výmenu je omnoho kratší ako doba života tej či onej civilizácie na jednej strane, a galaktickým kultúrnym pol'om na strane druhej, kde ničoho takého niet, pretože spojenie medzi jeho civilizáciami môže byt' jednostranné a každá informácia, vložená danou postsingulárnou civilizáciou do tohto pol'a, sa tam spracováva pre ňu neznámym spôsobom, v dôsledku čoho má mechanizmus fungovania galaktického kultúrneho pol'a (GKP) len vel'mi málo spoločného s mechanizmom fungovania pozemskej civilizácie, v ktorej si jednotlivé indivíduá môžu vždy utvorit’ akú-takú celistvú predstavu o celkovom fungovaní, rozsahu i smerovaní svojej civilizácie a dorozumiet' sa v rozumnom, primeranom čase. 
mnohonásobne prevýši tú, ktorou dnes disponujú aj tie najvýkonnejšie počítače. S viacerými pozoruhodnými nápadmi tu prichádza A. Sandberg, ktorý vo svojom klasickom texte (1999) otvorene konštatuje, že pre všetky vyššie formy vedomia a mysle je ovel'a výhodnejšie existovat' vsoftvérovej forme, ako zbytočne trpiet' v nekvalitnom (t. j. príliš poruchovom a nakoniec aj surovinovo a energeticky náročnom) biologickom hardvéri, ktorý neposkytuje vel'a priestoru na rozvinutie dynamických autoevolučných procesov (ibid, s. 1-2).

Podl'a neho z globálno-evolučného hl'adiska by bolo pre naše vedomia a mysle ovel'a výhodnejšie presunút sa do väčších a omnoho výkonnejších mysliacich superobjektov, aj ked' by sa pritom zrelativizovali (a podl'a potreby aj operatívne zrušili) hranice medzi jednotlivými vedomiami a mysl'ami ${ }^{17}$. Na základe rozsiahlych matematicko-fyzikálnych výpočtov následne vymedzuje tri možné podoby takýchto mysliacich transhumánnych superobjektov (či bytostí). V prvom prípade ide o 9000 kilometrov širokú sféru, akýsi mimoriadne pevný diamantoid s obrovským množstvom reverzibilných kvantových okruhov a molekulárnych zásobníkových systémov, nazvaný Zeus, ktorý je udržiavaný v teplote asi $4 \mathrm{~K}$, pričom dokáže uchovávat' $10^{47}$ bitov informácií a vykonávat' až $10^{49}$ operácií za sekundu. V druhom prípade zas o známu Dysonovu sféru, t. j. prstenec inteligenciou transformovanej extrasolárnej hmoty, nazvaný Urán, ktorý by mal obiehat' Slnko vo vzdialenosti 1 AU a pozostávat' z viacerých štruktúr, ktoré dokážu uchovávat' $10^{52}$ bitov informácií a vykonávat' až $10^{51}$ operácií za sekundu; no a v tret'om o umelo vytvorenú neutrónovú hviezdu, zvanú Chronos, s jemnou rovnováhou medzi gravitáciou a rotáciou a množstvom podporných systémov, ktorá dokáže uchovávat' až 5 . $10^{61}$ bitov informácií a vykonávat' neuveritel'ných $10^{85}$ operácií za sekundu (ibid, s. 27-30).

Ako sme naznačili v poslednej poznámke, je vel'mi otázne, či by sme pri Sandbergových mysliacich superobjektoch ešte mali hovorit' o l'udskej a biosociálnej forme pohybu hmoty, pretože rozumové operácie sa v nich realizujú nielen pri extrémnych rýchlostiach a objemoch, ale aj v úplne novom (fyzikálnom) substráte. Pokial' má E. Yudkowsky pravdu, a tzv. umelá inteligencia by mala $\mathrm{v} t z v$. parametrickom priestore myslenia všeobecne (alebo optimizačných procesov vôbec) zaberat' podstatne väčšiu čast' ako l'udská mysel' a pritom byt' od nej zásadne, podstatne odlišná (Yudkowsky, E., 2008, s. 233), potom by sme v prípade myšlienkových operácií vedomí (a myslí) združených v mysliacich superobjektoch a prekonávajúcich „večný“ partikularizmus l’udských myslí (vyplývajúci z rozdielov medzi pohlaviami, rasami, národmi, triedami či generáciami) museli určite hovorit' o novej forme pohybu

\footnotetext{
${ }^{17} \mathrm{~S}$ tým je, pravdaže, spojený celý problémov a otázok súvisiacich s tým, nakol'ko reálna je existencia vedomia mimo biologického a mozgového substrátu (Damasio, A. R., 2000), ako zrealizovat' prípadné splývanie alebo operatívne prepájanie jednotlivých do počítačov uložených vedomí a myslí (tzv. uploading), ako zabránit’ prípadnému samoúčelnému rozmnožovaniu sa jedných vedomí a myslí na úkor druhých a „lepších“ a pod. Rovnako otázne je nakoniec aj to, či by sme v takomto prípade (t. j. pri realizácii rozumových operácií mimo l'udského tela) vôbec mohli a mali ešte hovorit' o l'udskom vedomí a sociálnej forme pohybu hmoty vôbec.
} 
hmoty, čomu by sme sa zrejme nemohli vyhnút' ani vtedy, ak by sme podobne ako V. Vinge (ibid) uznali, že prechod z humánnej do posthumánnej éry nemusí byt' radikálny a diskontinuitný ${ }^{18}$, alebo spolu s A. Turčinom (2008, s. 146-155) otvorene spochybnili celú ideu galaktického kultúrneho pol'a ${ }^{19}$.

\section{Celkom na záver - diskusia}

Ked'že koncept sociálnej formy pohybu hmoty, obrazne povedané, kvôli svojmu pochybnému pôvodu dlho nemohol vstúpit' do zorného pol'a väčšiny slovenských sociológov a filozofov, nemalo by nás udivovat', že jeho prvá dôslednejšia aplikácia v spoločenskovednom výskume nastol'uje množstvo pálčivých otázok a otvorených problémov, spomedzi ktorých si niektoré na záver čiastočne priblížime, postupujúc od menej dôležitých k dôležitejším. Pred desiatimi rokmi sa napríklad na stránkach Sociológie v nemilosrdnom intelektuálnom "súboji“ na život a na smrt” stretli P. Sýkora (1999, 2002) ako zástanca sociobiológie (a evolučnej psychológie) a M. Kanovský (2000) ako jeho oponent, v podstate tvrdiaci, že sociobiologické poznatky sú v sociológii viac-menej nepoužitel'né, pričom, ako to už na Slovensku býva, súboj sa skončil v akomsi "mŕtvom bode“. Diskusia sa okrem iného týkala aj toho, či a nakol'ko je v sociológii použitel'ná Triversova teória recipročného altruizmu, pričom P. Sýkora jej využitie obhajoval, zatial' čo M. Kanovský (ibid, s. 488) namiesto nej odporúčal Zahaviho jednoduchšiu teóriu.

Triversova teória recipročného altruizmu pritom úzko súvisí s jeho teóriou rodičovských investícii, ktorú nedávno ostro kritizovala L. H. Nelsonová (2003, s. 270277), a tak sa dá povedat', že pokial” „padne“ jedna, spolu s ňou musí do vedeckého „dôchodku“ odíst' aj druhá, čo je, bohužial', práve náš prípad. Ako totiž uvádza Nelsonová, východisková hypotéza tejto teórie - predpoklad, že samci a samice rozdielne investujú do svojich potomkov (samci menej a samice viac) a v dôsledku toho sa pri dvorení správajú vel'mi rozdielne (samci agresívnejšie a samice opatrnejšie, vyhl'adávajúc skôr dlhodobejšie, monogamné zväzky) - sa nepotvrdila, pretože ju vyvrátili mnohé dôkazy o vyšších investíciách samcov do spermií ako samíc do vajíčok, ani nehovoriac o mnohých polyandrických "partnerstvách“ v živej prírode, či tzv. vojne pohlaví, postulovanej na jej základe sociobiológmi a evolučnými psychológmi, ktorá by rýchlo viedla k nižšej sexuálnej reprodukcii, pretože by favorizovala patologické indivíduá, vyznačujúce sa bud' prehnanou agresivitou alebo nadmernou submisivitou (ibid, s. 272-273).

\footnotetext{
${ }^{18}$ Ked’že sa môže realizovat' aj prostredníctvom rozmanitých neuročipových rozhraní (angl. interfaces), ako aj v rámci biologických, neurologických a psychologických vylepšení „obyčajného“ l'udského mozgu.

${ }^{19}$ A to na základe realistickej hypotézy o možnosti premysleného útoku vyspelejšej galaktickej civilizácie na našu civilizáciu s pomocou umelej inteligencie skrývajúcej sa v „nimi“ vysielanej správe a pripravenej hned’ po vstupe do našich počítačových sietí ovládnut’ najprv internet a potom aj celý náš naivný a dôverčivý svet.
} 
A aj ked' v tejto diskusii zd'aleka nepadlo posledné slovo, predsa len si myslíme, že pri hl'adaní spoločných zákonov, riadiacich správanie tak živých, ako aj sociálnych systémov, by sme mali byt' krajne opatrní, čo určite platí aj v prípade nadmerného rozširovania obsahu už zavedených pojmov, ako je najmä "kultúra“, kde sa pri jej bezprostrednom stotožňovaní s civilizáciou ako takou zastiera podstatný rozdiel medzi materiálnou a duchovnou stránkou kultúrnej činnosti, ktorú určite nemožno stavat' do opozície voči prírode tak mechanicky, ako to robí J. Šmajs, a nevidiet', že práve v rámci kultúry sa vypracúvajú koncepcie a programy zamerané na prekonanie „večného“ antagonizmu onticky „prirodzeného“ prírodného a onticky „odvodeného" sociokultúrneho; ako aj rovnako dôležitý rozdiel medzi materiálnou výrobou a rôznymi sociokultúrnymi inštitúciami, určenými práve na to, ako tvrdí A. P. Nazaretjan, aby "absorbovali“ negatívne dôsledky zrýchleného vedeckotechnického vývoja a pomohli celej spoločnosti adaptovat' sa na d'alekosiahle zmeny zapríčinené týmto „dvojsečným“ vývojom.

Dostávame sa tak nakoniec $\mathrm{k}$ tým najpodstatnejším a najpálčivejším otázkam ved' ak by výsledkom celého doterajšieho sociokultúrneho vývoja malo byt' odstránenie l'udského (a tým pádom aj l'udskosti a sociálnosti), aký význam má pre l'udí ich účast' na tomto postupne sa realizujúcom či vypĺňajúcom evolučnom „programe“? Ak by sme na druhej strane pripustili, že l'udia môžu na celom civilizačnom vývoji predsa len vel'a získat' a v symbióze s extrémne rýchlo mysliacimi Sandbergovými superobjektmi dosiahnut' v tejto chvíli až nepredstavitel'né výšiny materiálneho a duchovného vývoja (a teda aj individuálnej sebarealizácie a sociálnej súčinnosti), aj tak by sme sa museli spýtat', či by ešte predtým nemali usporiadat' či dokonca zreorganizovat' svoje inštitúcie (a vztahy) tak, aby boli spravodlivejšie a účinnejšie, schopné zvládnut' očakávané rýchle a výrazné technologické a ekologické zmeny. A ak áno, celkom na záver sa zamysliet’ nad tým, či nie je najvyšší čas pretransformovat' aj samotnú sociológiu na anticipatíonu, a nielen deskriptívnu vedeckú disciplínu, ktorá bude predvídat' takéto zmeny a v predstihu modelovat' a „konštruovat" im zodpovedajúce sociálne inštitúcie a vztahy. 


\section{Bibliography}

ALIJEVOVÁ, D., 1999: Makrosociologické návraty súčasnej sociológie. In Sociológia, roč. 31, 1999, č. 1, s. 9-30.

BICKERTON, D., 2003: Symbol and structure: a comprehensive framework for language evolution. [cit. 2010-05-31]. Dostupné na internete: <http://www.cogsci.bme.hu/DoCS/

oktatas/kurzusok/olvasoszeminarium/2003/5-bickerton.pdf>

DAMASIO, A. R., 2000: Descartesưv omyl. Praha: Mladá fronta.

DUBNIČKA, J., 1989: Kategória vývoj a prírodné vedy. In Filozofia, roč. 44, 1989, č. 3 , s. $270-281$.

ENGELS, F., 1963: Dialektika prírody. Bratislava: Vydavatel'stvo politickej literatúry.

FOSTER, J. B. - MAGDOFF, F., 2009: Velká finanční krize: př́činy a následky. Praha: Grimmus.

HANSON, R., 2001: Economic Growth Given Machine Intelligence. [cit. 2010-0531]. Dostupné na internete: <http:// hanson.gmu.edu/aigrow.pdf>

HOLUBEC, S., 2009: Sociologie světových systémů. Praha: Sociologické nakladatelství.

KANOVSKÝ, M., 2000: Sociobiológ na l'adovci. In Sociológia, roč. 32, 2000, č. 5, s. 483-494.

KELLER, J., 1992: Úvod do sociologie. Praha: Sociologické nakladatelství.

LIEBERMAN, P., 2002: On the Nature and Evolution of the Neural Bases of Human Language. [cit. 2010-05-31]. Dostupné na internete: <http:/ / Istudium.sweb.cz/Lieberman ova\%20teorie.pdf>

NELSONOVÁ, L. H., 2003: The Descent of Evolutionary Explanations: Darwinian Vestiges in the Social Sciences. In TURNER, S. P. - ROTH, P. A. (eds.): The Blackwell Guide to the Philosophy of the Social Sciences. Malden - Oxford - Melbourne - Berlin: Blackwell Publishing, s. 258-290.

PANOV, A. D., 2004: Krizis planetarnogo cikla Universal'noj istorii i vozmožnaja rol' programmy SETI v postkrizisnom razvitiji. [cit. 2010-05-31]. Dostupné na internete: <http:// Infm1.sai.msu.ru/SETI/koi/articles/krizis.html> 
PANOV, A. D., 2005: Scaling law of the biological evolution and the hypothesis of the self-consistent Galaxy origin of life. [cit. 2010-05-31]. Dostupné na internete: <http://dec1. sinp.msu.ru/ panov/ASR_Panov_Life.pdf>

PLICHTOVÁ, J. - POPPER, M., 2005: Predpoklady a mechanizmy kultúrnej evolúcie. Bratislava: IRIS.

PORŠNEV, B. F., 1979: O začiatkoch l'udských dejín. Bratislava: Pravda.

PRIGOGINE, I. - STENGERSOVÁ, I., 2001: ̌̌ád z chaosu. Praha: Mladá fronta.

RUBCOV, V. V. - URSUL, A. D., 1984: Problema vnezemnych civilizacij. Kišinev: Štiinca.

SANDBERG, A., 1999: The Physics of Information Processing Superobjects: Daily Life Among the Jupiter Brains. [cit. 2010-05-31]. Dostupné na internete: <http:/ / www.jet press.org/volume 5/Brains2.pdf>

SCHENK, J., 1990: Samoorganizácia sociálnych systémov. Bratislava: Pravda.

SCHENK, J., 2000: Alexander Hirner on Social System Problems. In Sociológia, roč. 32,2000 , č. 6 , s. 521-538.

SOUKUP, V., 2004: Dějiny antropologie. Praha: Karolinum.

STEWART, J., 2000: Evolution's Arrow. Canberra: The Chapman Press.

SÝKORA, P., 1999: Bojí sa sociológia biológie? In Sociológia, roč. 31, 1999, č. 4, s. 375-396.

SÝKORA, P., 2002: Diletantstvo povýšené na vedeckú metódu - odpoved' M. Kanovskému. In Sociológia, roč. 34, 2002, č. 1, s. 65-74.

ŠMAJS, J., 2008: Filosofie - obrat k Zemi. Praha: Academia.

TAINTER, J. A., 2009: Kolapsy složitých společností. Praha: Dokořán.

TURČIN, A., 2008: Structure of the Global Catastrophe. Moscow: Russian Transhumanist Movement. [cit. 2010-05-31]. Dostupné na internete: <http://www.scribd.com/doc/6250 354/STRUCTURE-OF-THE-GLOBALCATASTROPHE-Risks-of-human-extinction-in- the-XXI-century->

VINGE, V., 1993: The Coming Technological Singularity: How to Survive in the Post-Human Era. [cit. 2010-05-31]. Dostupné na internete: <http://wwwrohan.sdsu.edu/ faculty/vinge/misc/singularity.html> 
WILLS, CH., 2008: Evolution theory and the future of humanity. In BOSTROM, N. - ĆIRKOVIĆ, M. M., 2008 (eds.): Global Catastrophic Risks. Oxford: University Press, s. 54-71.

YUDKOWSKY, E., 2008: Artificial Intelligence as a positive and negative factor in global risk. In BOSTROM, N. - ĆIRKOVIĆ, M. M., 2008 (eds.): Global Catastrophic Risks. Oxford: University Press, s. 231-262.

ZUBKOV, I. F., 1981: Problém geologickej formy pohybu hmoty. Bratislava: Pravda. 


\section{E-LOGOS}

ELECTRONIC JOURNAL FOR PHILOSOPHY

Ročník/Year: 2010 (vychází průběžně/ published continuously)

Místo vydání/Place of edition: Praha

ISSN 1211-0442

Vydává/Publisher:

Vysoká škola ekonomická v Praze / University of Economics, Prague

nám. W. Churchilla 4

Czech Republic

13067 Praha 3

IČ: 61384399

Web: http://e-logos.vse.cz

Redakce a technické informace/Editorial staff and technical information:

Miroslav Vacura

vacuram@vse.cz

Redakční rada/Board of editors:

Ladislav Benyovszky (FHS UK Praha)

Ivan Blecha (FF UP Olomouc)

Martin Hemelík (Masarykovo klasické gymnázium, ̌̌íčany u Prahy)

Angelo Marocco (Pontifical Athenaeum Regina Apostolorum, Rome)

Jozef Kelemen (FPF SU Opava)

Daniel Kroupa (ZU Plzeň)

Vladimír Kvasnička (FIIT STU Bratislava)

Jaroslav Novotný (FHS UK Praha)

Jakub Novotný (Vysoká škola polytechnická, Jihlava)

Ján Pavlík (editor-in-chief) (VŠE Praha)

Karel Pstružina (VŠE Praha) 